\title{
Spinal anesthesia for elective ceasarean section. Use of different doses of hyperbaric bupivacaine associated with morphine and clonidine ${ }^{1}$
}

\author{
Angélica de Fátima de Assunção Braga', José Aristeu Fachini Frias ${ }^{\mathrm{II}}$, Franklin Sarmento da Silva \\ Braga $^{\text {III, Rosa Inês Costa Pereira }}{ }^{\text {III, Stella Marys Meirelles Campos Titotto }}{ }^{\text {IV }}$
}
'Associate Professor, Department of Anesthesiology, UNICAMP, Campinas-SP, Brazil. Intellectual and scientific content of the study, acquisition and interpretation of data, manuscript preparation and writing, critical revision, designed the protocol, involved whit technical procedures, supervised all phases of the study.

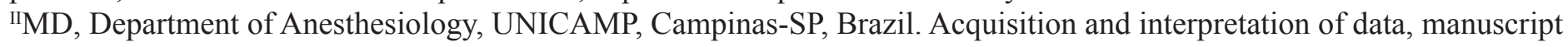 preparation and writing, critical revision.
IIIPhD, Department of Anesthesiology, Faculty of Medical Sciences, UNICAMP, Campinas-SP, Brazil. Advisor and critical revision.
${ }^{\mathrm{IV}} \mathrm{MD}$, Anesthesiologist, Department of Anesthesiology, Faculty of Medical Sciences, UNICAMP, Campinas-SP, Brazil. Acquisition and interpretation of data, manuscript preparation and writing.

\begin{abstract}
PURPOSE: To comparatively study the efficacy and maternal and fetal side-effects of two doses of bupivacaine associated with morphine and clonidine, administered by the subarachnoid route for cesarean section.

METHODS: The study included 66 pregnant women at term, distributed into two groups. GI: bupivacaine $8.0 \mathrm{mg}(1.6 \mathrm{~mL})$ + clonidine $75 \mu \mathrm{g}(0.5 \mathrm{~mL})+$ morphine $100 \mu \mathrm{g}(1.0 \mathrm{~mL})$ and GII: bupivacaine $10 \mathrm{mg}(2.0 \mathrm{~mL})+$ clonidine $75 \mu \mathrm{g}(0.5 \mathrm{~mL})+$ morphine $100 \mu \mathrm{g}(1.0 \mathrm{~mL})$. The following parameters were assessed: onset and maximum level of sensory block; quality of intraoperative and postoperative analgesia; degree and duration of motor block; maternal repercussions and Apgar score.

RESULTS: The onset of sensory block, quality of intraoperative analgesia and total duration of analgesia were similar in both groups; maximum extent of sensory block predominated in T4; maximum degree of motor block (Bromage 3); time motor block regression was significantly longer in GII; Hemodynamic, respiratory repercussions, adverse maternal effects and Apgar scores were similar between groups. In both groups, there was a predominance of drowsy or sleeping patients.

CONCLUSION: The addition of morphine and clonidine to low doses of hyperbaric bupivacaine produced adequate anesthesia for cesarean section and good postoperative analgesia, without any maternal and fetal repercussions.
\end{abstract}

Key words: Adrenergic alpha-2 Receptor Agonists. Clonidine. Analgesics, Opioid. Morphine. Cesarean Section. 


\section{Introduction}

Hyperbaric bupivacaine in spinal anesthesia is commonly used for the performance of cesarean delivery. Its association with adjuvant drugs not only improves the quality of intraoperative analgesia and prolongs postoperative analgesia, but allows use of smaller doses, decreasing the risk of maternal hypotension and damage to the fetus ${ }^{1-5}$. Subarachnoid opioids have been used for acute and chronic pain control ${ }^{2,3}$. Clonidine, a partial agonist of $\alpha_{2}$-adrenergic receptors, interacts with local anesthetics in the neural axis. The analgesic effect of the drug is quite evident, due to its action on spinal and supraspinal $\alpha_{2}$-adrenergic receptors (CNS), including activation of $\alpha_{2}$ postsynaptic receptors from noradrenergic descending pathways of cholinergic neurons and the release of nitric oxide and substances such as encephalin ${ }^{5-7}$. In cesarean section, the morphine dose recommended to produce satisfactory intra- and postoperative analgesia is 100 to $200 \mu \mathrm{g}$, while the recommended for clonidine doses range from 15 to $150 \mu \mathrm{g}^{2,6-8}$.

The aim of this study was to comparatively evaluate the effectiveness of different doses of hyperbaric bupivacaine associated with morphine and clonidine in the quality of block and maternal and neonatal repercussions, in pregnant women undergoing cesarean section under spinal anesthesia.

\section{Methods}

The study was performed after obtaining approval from the Medical Research Ethics Committee of the institution (CEPnumber 325/2011) and informed consent signature. This was a double-blind, randomized clinical trial, which consecutively included pregnant women at term, physical status ASA 1 and 2, undergoing elective cesarean section and receiving spinal anesthesia. Exclusion criteria were: contraindications to spinal block, prematurity, multiple pregnancy, preeclampsia, history of hypersensitivity to drugs used, previous administration of opioids and/or other CNS depressants, Body Mass Index (BMI) $>40$.

Based on the results of Braga et al. ${ }^{9}$, considering that the dependent variable time for motor block regression was 255.75 \pm 71.47 minutes, when a combination of bupivacaine $10 \mathrm{mg}+$ clonidine $75 \mu \mathrm{g}+$ morphine $100 \mu \mathrm{g}$ was used in the subarachnoid space, and assuming that decreasing bupivacaine dose to $8 \mathrm{mg}$ associated with the same adjuvants in the same doses (clonidine $75 \mu \mathrm{g}+$ morphine $100 \mu \mathrm{g})$, time for motor block regression would be reduced by $20 \%$. Using type error (0.05) and type $\beta$ error $(0.2)$ - a power of test of $80 \%$, the number of cases calculated per group was 33. Therefore, an "n" of 66 subjects distributed into 2 groups was required to assess the differences existing between groups for the variable studied.

Sixty-six (66) subjects were randomly allocated to 2 groups (GI and GII), using randomization software (SAS 9.1). Both the anesthesiologist performing the block and the anesthesiologist evaluating the parameters studied were blinded to the idenity of the spinal solution employed.

In both groups, the LA used was hyperbaric bupivacaine $0.5 \%$ associated with adjuvant morphine and clonidine. Two groups were formed, according to the dose of bupivacaine used: GI bupivacaine $8.0 \mathrm{mg}(1.6 \mathrm{~mL})+$ clonidine $75 \mu \mathrm{g}(0.5 \mathrm{~mL})+$ morphine $100 \mu \mathrm{g}(1.0 \mathrm{~mL})+$ saline $0.9 \%(0.9 \mathrm{~mL})$; GII-bupivacaine $10 \mathrm{mg}$ $(2.0 \mathrm{~mL})+$ clonidine $75 \mu \mathrm{g}(0.5 \mathrm{~mL})+$ morphine $100 \mu \mathrm{g}(1.0 \mathrm{~mL})$ + saline $0.9 \%(0.5 \mathrm{~mL})$. Saline $0.9 \%$ was added to the solution in both groups to obtain a total volume of $4 \mathrm{~mL}$. The drugs used were commercial products supplied by only one manufacturer, without determination of lot number. Solution densities were analyzed by the laboratory manufacturing the drugs, using digital density meter Anton Paar Model DMA 4500, previously calibrated with milli-Q water at $37^{\circ} \mathrm{C}$. The characteristics of the resulting solutions are found in Table 1.

TABLE 1 - Characteristics of anesthetic solutions.

\begin{tabular}{cccccc}
\hline & $\begin{array}{c}\text { volume } \\
\text { (mL) }\end{array}$ & $\begin{array}{c}\text { density } \\
\text { at } 37^{\circ} \mathrm{C} \\
(\mathrm{g} . \mathrm{mL}-1)\end{array}$ & bupivacaine & clonidine & morphine \\
\hline Group I & 4 & 1.0107 & 8 & $\mu \mathrm{g}$ & $\mu \mathrm{g}$ \\
Group II & 4 & 1.0125 & 10 & 75 & 100 \\
\hline
\end{tabular}

The pregnant women were fasted and had not been given any preanesthetic medication. In the operating room, all were continuously monitored with cardioscope in DII lead, noninvasive arterial blood pressure monitor and pulse oximeter. After venous access with an $18 \mathrm{G}$ cannula, 500 to $750 \mathrm{~mL}$ of lactated Ringer's solution was administered before the spinal block. Subarachnoid anesthesia was performed at the L3-L4 interspace with the patients in the sitting position. A Whitacre $27 \mathrm{G}$ or Quincke $25 \mathrm{G}$ needle was used, in case of a technically difficult spinal anesthesia. The anesthetic solution was injected at a rate of $1 \mathrm{~mL} .15 \mathrm{~s}^{-1}$, without barbotage. After performance of the spinal block, the pregnant women were placed in the supine position, and a Crawford wedge was used for left uterine displacement until birth. Supplemental oxygen was administered ( 2 to 3 L.min ${ }^{-1}$ ) with the aid of nasal prongs. Hydration was maintained with lactated Ringer solution 
$\left(10 \mathrm{~mL} \cdot \mathrm{kg}^{-1} \cdot\right.$ hour $\left.^{-1}\right)$. The following parameters were studied: 1) onset of sensory block - time elapsed from the end of intrathecal injection of the anesthetic (evaluated each minute) to loss of painful pinprick sensation in $\mathrm{T} 10 ; 2$ ) maximum level of sensory block-evaluated 20 minutes after the end of anesthetic injection; 3) maximum level of motor block - evaluated 20 minutes after the end of anesthetic injection, according to a modified Bromage scale: $0=$ free movement of the lower limbs (nil); $1=$ able to flex knees and move feet; 2 = just able to flex feet; 3 = completely unable to move lower limbs; 4) time for motor block regression- time interval between end of anesthetic injection in the subarachnoid space and free movement of the lower limbs $(0-$ nil $) ; 5)$ discomfort in the intraoperative period - complaint of pain (VNS $\geq 3$ ) requiring the intravenous use of opioid (fentanyl $100 \mu \mathrm{g}$ ) associated with midazolam (1 to $2 \mathrm{mg}$ ); 6) total duration of analgesia - time interval between the end of solution injection in the subarachnoid space and spontaneous complaint of pain (VNS $\geq 3$ ) reported by the patient during stay in the postanesthetic care unit (PACU). The use of tenoxicam (40mg) and dipyrone (30 mg. $\left.\mathrm{kg}^{-1}\right)$ was adopted, only after the first spontaneous complaint of pain (VNS $\geq 3$ ), while in the PACU; 7) maternal cardiovascular and respiratory parameters: mean arterial pressure (PAM - $\mathrm{mmHg}$ ), heart rate (HRbeats per minute), respiratory rate (breaths per minute) and oxygen saturation $\left(\mathrm{SpO}_{2}-\%\right)$, were assessed in the following time points: before the block (M0); immediately after the block (M1); every five minutes during surgery (M2); and at the end of surgery (M3); 8) level of consciousness in the intraoperative period, according to a scale proposed by Filos et al. ${ }^{10}$ and modified by Braz et al. ${ }^{11}: 1=$ awake (anxious, agitated); 2= awake (calm); 3=drowsy; 4=asleep (awakes with verbal stimulation); 9) intraoperative maternal side-effects: nausea, vomiting, pruritus, respiratory depression ( $\mathrm{SpO} 2 \leq 90 \%$ and respiratory rate below $10 \mathrm{rpm}$ ); 10) neonatal repercussions: through the Apgar score at one and five minutes.

Arterial hypotension was defined as a mean arterial blood pressure less than $70 \mathrm{mmHg}$. If present, hypotension was treated with a rapid infusion of crystalloid solution. If persistent, it was treated with ephedrine ( $5 \mathrm{mg}$ - venous bolus); bradycardia was defined as a decrease in heart rate for values below 50 beats per minute and it was treated with atropine $\left(10-20 \mu \mathrm{g} \cdot \mathrm{kg}^{-1}\right)$. In anxious and agitated patients, use of venous midazolam (1.0 to $5.0 \mathrm{mg}$ ) was recommended.

Fetal extraction time was defined as the interval from skin incision to placental delivery. The duration of surgery (minutes) was defined as the interval from skin incision to the end of surgery.

\section{Statistical analysis}

For statistical analysis of patient characteristics, the ANOVA test was used. To study the onset of sensory block, duration of analgesia, and time for motor block regression, the Student's t test was used; for degree of motor block, level of sensory block, ephedrine requirement, maternal side-effects and level of consciousness; incidence of hypotension, the chi-square test was used; for intraoperative discomfort, Fisher's exact test was used. On statistical analysis of cardiovascular and respiratory parameters, $M_{2}$ was the time point considered the average of the mean values obtained in 5-minute intervals during surgery and the MANOVA test was used. The level of significance was set at $5 \%$.

\section{Results}

Anthropometric data analysis showed a significance difference between the groups, regarding height and body mass index (Table 2). The mean time and standard deviation for surgery duration (minutes) and fetal extraction (minutes) were: $75.48 \pm$ 13.29 and $17.48 \pm 5.50$, in GI and $74.75 \pm 14.69$ and $16.15 \pm 5.58$ in GII, respectively. There was no significant difference between the groups $(p=0.44)$.

TABLE 2 - Anthropometric data.

\begin{tabular}{cccc}
\hline & $\begin{array}{c}\text { Group I } \\
(\mathbf{n}=\mathbf{3 3})\end{array}$ & $\begin{array}{c}\text { Group II } \\
(\mathbf{n}=\mathbf{3 3})\end{array}$ & $\mathrm{p}$ \\
\hline Age (years)* & $31.91 \pm 6.35$ & $29.27 \pm 6.25$ & 0.23 \\
Weight $(\mathrm{Kg})^{*}$ & $81.00 \pm 11.90$ & $79.34 \pm 11.52$ & 0.54 \\
Height $(\mathrm{m})^{*}$ & $1.59 \pm 0.05$ & $1.62 \pm 0.06$ & 0.024 \\
BMI $\left(\mathrm{kg} . \mathrm{m}^{-2}\right)^{*}$ & $32.00 \pm 4.05$ & $30.20 \pm 3.62$ & 0.027 \\
\hline
\end{tabular}

Values expressed in Mean \pm SD

*Student's t test

The onset of sensory block was similar between groups $(\mathrm{p}=0.43)$. For maximum level of sensory block, there was a predominance of T4 level in more than $70 \%$ of cases, without any significant difference between groups. In both groups, the majority of patients had level 3 motor block and the time for motor block regression was significantly longer $(p=0.00073)$ in GII. In the intraoperative period, a mean time of $65.00 \pm 10.00$ minutes, the number of patients reporting pain (VNS $\geq 3$ ) was similar in both groups $(\mathrm{p}=0.11)$. In GI, four patients required fentanyl $(100 \mu \mathrm{g})$ and midazolam $(2.0 \mathrm{mg})$ intravenously. Both groups showed similarities in the total duration of analgesia and number of patients reporting pain (VNS $\geq 3$ ) in the immediate postoperative period (PAC). Data relative to block characteristics are found in Table 3. 
TABLE 3 - Block characteristics.

\begin{tabular}{cccc}
\hline & Group I & Group II & $\mathrm{p}$ \\
\hline $\begin{array}{c}\text { Onset of sensory } \\
\text { block (min)* }\end{array}$ & $3.88 \pm 1.32$ & $3.93 \pm 1.63$ & 0.43 \\
$\begin{array}{c}\text { Maximum level of } \\
\text { sensory block** }\end{array}$ & & & \\
$\mathrm{T}_{2}$ & $05(15.1 \%)$ & $02(6 \%)$ & 0.25 \\
$\mathrm{~T}_{4}$ & $24(72.7 \%)$ & $27(81.8 \%)$ & 0.77 \\
$\mathrm{~T}_{6}$ & $06(18.1 \%)$ & $04(12.1 \%)$ & 0.36 \\
$\begin{array}{c}\text { Total duration of } \\
\text { analgesia (min) }\end{array}$ & $163.66 \pm 25.67$ & $191.18 \pm 41.99$ & 0.38 \\
$\mathrm{n}$ & $12(36.36 \%)$ & $11(33.33 \%)$ & 0.25 \\
$\begin{array}{c}\text { Degree of motor } \\
\text { block** }\end{array}$ & & & \\
2 & $01(3 \%)$ & $01(3 \%)$ & \\
3 & $32(96.9 \%)$ & $32(96.9 \%)$ & \\
$\begin{array}{c}\text { Time for motor } \\
\text { block regression* }\end{array}$ & $198.48 \pm 47.63$ & $232.84 \pm 63.66$ & 0.00073 \\
\hline
\end{tabular}

Values expressed in Mean $\pm \mathrm{SD}$; number (n) and percentage of patients (\%)

*Student's t test

**Chi-square test

Hemodynamic repercussions were similar between the groups. A comparison of mean MAP and HR values, in the different time periods studied, did not show any significant difference between groups $(\mathrm{p}>0.05)$. Individual analysis of cardiovascular parameters indicated arterial hypotension (MAP $<70 \mathrm{mmHg}$ ) in M2 (intraoperative period- 15 minutes), in nine and 16 patients from groups I and II, respectively, without any significant difference $(\mathrm{p}=0.055)$ and in 22 patients from GI and in 20 from GII, in M2 - 60 min, without any significant difference $(p=0.07)$. The number of patients requiring ephedrine totaled 14 and 18 in groups I and II, respectively, without any significant difference $(p=0.97)$. The mean dose of ephedrine used in both groups I and II was $13.9 \mathrm{mg}$ and $9.5 \mathrm{mg}$, respectively, without any significant difference $(p=0.06)$.

In both groups, individual analysis showed a decrease in HR $(<50 \mathrm{bpm})$ in seven patients, with four in Group I and three in Group II. This event occurred in the PACU, and the use of intravenous atropine was necessary $(0.5 \mathrm{mg})$.

All patients maintained respiratory rate above 10 breaths per minute and peripheral $\mathrm{O}_{2}$ saturation between 95 and $100 \%$. In both groups, the Apgar score ranged from 8 to 10 and 9 to 10 at one and five minutes, respectively.

Concerning the level of consciousness (Table 4), a predominance of drowsy or sleeping patients was observed in both groups. In group I, two patients were anxious (score 1).

TABLE 4 - Level of consciousness.

\begin{tabular}{ccc}
\hline & Group I & Group II \\
\hline \hline Anxious & $02(6 \%)$ & $0(0 \%)$ \\
Calm & $06(18.1 \%)$ & $06(18.1 \%)$ \\
Drowsy & $11(33.3 \%)$ & $13(39.3 \%)$ \\
Asleep & $14(42.4 \%)$ & $14(42.4 \%)$ \\
\hline
\end{tabular}

Values expressed in number and percentage of patients $(\%)$

The incidence of maternal side-effects is shown in Table 5 and occurred in a similar manner between groups. Nausea and vomiting were observed especially in the presence of arterial hypotension and at the time of the revision of the abdominal cavity. Pruritus was reported in the intraoperative and postoperative periods (PARU).

TABLE 5 - Adverse effects.

\begin{tabular}{ccc}
\hline & Group I & Group II \\
\hline \hline Nausea & $10(30.3 \%)$ & $11(33.3 \%)$ \\
Vomiting & $04(12.1 \%)$ & $05(15.11 \%)$ \\
Pruritus & $24(72.7 \%)$ & $28(84.8 \%)$ \\
\hline
\end{tabular}

Values expressed in number and percentage of patients (\%)

\section{Discussion}

Most cesarean sections are performed under spinal anesthesia, involving the association between local anesthetics and subarachnoid adjuvants such as opioids and alpha $a_{2}$-agonists. The reason to combine drugs is because the use of low doses ( 7.5 to $10 \mathrm{mg}$ ) of spinal hyperbaric bupivacaine alone has been shown to be insufficient to produce adequate perioperative analgesia. The incidence of pain is reported to be around $71 \%{ }^{1}$. A higher incidence of arterial hypotension ( 50 a $85 \%$ ) has been described with the use of higher doses (12 to $15 \mathrm{mg})^{2,12-14}$ of hyperbaric bupivacaine. In addition to high doses of local anesthetics, other factors may contribute to a higher incidence of arterial hypotension ${ }^{15-18}$, such as oxytocin infusion and factors involved in the cephalic spread of local anesthetics in the cerebrospinal fluid.

The slow onset of action of morphine can explain the low efficacy in the quality of surgical analgesia and also contributes to the delayed appearance of adverse effects, such as respiratory depression, pruritus, urinary retention, postoperative nausea and 
vomiting. The incidence of these effects is minimized by the use of low spinal doses of morphine $(100 \mu \mathrm{g})$, as recommended for cesarean section and used in this study, without compromising the quality of postoperative analgesia ${ }^{2,19-25}$.

Another class of drugs highlighted as adjuvants in spinal anesthesia includes the $\alpha_{2}$-adrenergic agonists. Its main representative is clonidine which interacts with local anesthetics, increasing potassium conductance in isolated neurons. This action intensifies and prolongs the conduction block of local anesthetics. It indirectly reduces the absorption of local anesthetics by a vasoconstrictor effect, mediated by $\alpha_{2}$ postsynaptic receptors, improving the quality and increasing the duration of the anesthetic block. Its mechanism of antinociception is due to action on $\alpha_{2}$ adrenoceptors in the dorsal horn of the spinal cord. This effect seems to be more intense during pregnancy $4,5,7,8,22,26-28$.

Although the literature reports clonidine doses ranging from 15 to $150 \mu \mathrm{g}$, in conjunction with local anesthetics and opioids for subarachnoid use in cesarean section, there is still no consensus on the best dose to use in this type of procedure. Recently, a dose of $1.0 \mu \mathrm{g} / \mathrm{kg}$ of clonidine combined with bupivacaine has been recommended. However, good results have been obtained with doses of $150 \mu \mathrm{g}$. Higher doses should be avoided because of greater hemodynamic repercussions $\mathrm{s}^{4,8,16,26,27,29}$.

Owing to its sympatholytic action in the CNS and peripheral nerve endings, clonidine can produce hypotension and bradycardia, mainly manifested more than 30 minutes after intrathecal injection ${ }^{22,30}$. In this study, hemodynamic alterations occurred mainly in the intraoperative period in both groups. However, these changes were not significant and occurred after birth. The number of patients presenting with arterial hypotension and requiring ephedrine in the intraoperative period was higher in group II, a fact attributed to the higher dose of bupivacaine used, since the doses of the adjuvant agents were the same and the maximum level of sensory block was similar in both groups.

Similar to our results, Lavand'homme et al. ${ }^{8}$ using different doses of bupivacaine (9 to $11 \mathrm{mg}$ ) associated with two doses of clonidine ( 75 and $150 \mu \mathrm{g}$ ), also did not observe significant alterations in arterial blood pressure in the first 30 minutes. However, with a dose of $150 \mu \mathrm{g}$, those authors reported significant alterations in arterial blood pressure, 30 minutes after administration. In another study ${ }^{26}$, using bupivacaine doses equivalent to those employed in this study (8.0 and 10mg) associated with $50 \mu \mathrm{g}$ of clonidine, arterial hypotension was observed at 25 minutes after the performance of the block in 35\% and $57 \%$ dos patients, respectively, and the authors concluded that this was a dose-dependent effect of bupivacaine.
Regarding heart rate, the mean heart rate values decreased 30 minutes after the block, without bradycardia (HR $\leq 50 \mathrm{bpm}$ ). However, individual analysis showed that 45 minutes after the block the use of atropine was required in $12 \%$ and $9 \%$ of patients in groups I and II, respectively. These findings are similar to those found by Lavand'homme et al. ${ }^{8}$, who observed bradycardia in $7 \%$ and $13 \%$ of the patients 30 minutes after the use of two different doses of clonidine, $75 \mu \mathrm{g}$ and $150 \mu \mathrm{g}$, respectively, justifying the dose-dependent bradycardic effect of clonidine.

The adverse effects on the product of conception, due to hemodynamic repercussions, were controlled by left uterine displacement, volume expansion and ephedrine. Therefore, newborns did not show any signs of fetal distress, with results similar to those described in the literature confirming the safety of drug combination used ${ }^{2,22,28}$.

The total duration of analgesia was similar in both groups, observing that $36 \%$ and $33 \%$ of patients in groups I and II reported pain after the block in the postanesthesia care unit at 163 and 191 minutes, respectively. Dipyrone and tenoxicam were used for pain control. Other authors ${ }^{7}$ evaluating the analgesic efficacy of the combined use of hyperbaric bupivacaine $(12.5 \mathrm{mg})$ and morphine $100 \mu \mathrm{g}$ and two doses of clonidine (15 and $30 \mu \mathrm{g})$ in cesarean section, reported the absence of intraoperative pain and a mean time period of analgesia of 712 and 902 minutes, respectively, with the two different doses of clonidine.

Other studies have shown that the analgesic effect of intrathecal clonidine (50 to $150 \mu \mathrm{g}$ ) associated with $0.5 \%$ hyperbaric bupivacaine ( 8.0 to $11 \mathrm{mg}$ ), without morphine, and with or without a lipid soluble opioid, usually does not last longer than 246 minutes $^{8,26,27}$.

In our study, pain in the intraoperative period was reported by four patients in the group receiving the lower dose of bupivacaine and occurred in a mean time period of 65 minutes. These findings are in agreement with those reported by Kothari et al. ${ }^{26}$ who used the same doses of bupivacaine employed in this study, associated with only $50 \mu \mathrm{g}$ of clonidine, and also observed discomfort in $4.28 \%$ of patients from the group receiving $8 \mathrm{mg}$ of bupivacaine in the intraoperative period.

Concerning time for motor block regression, it was significantly longer in the group using $10 \mathrm{mg}$ of bupivacaine. Although data in the literature $e^{4,27,28}$ confirm that clonidine potentiates the motor block produced by local anesthetics, the difference found between both groups may be attributed to a higher dose of bupivacaine used in group II, since the dose of clonidine was the same in all patients studied.

Due to the activation of $\alpha_{2}$-adrenergic receptors in the 
Central Nervous System (CNS), clonidine causes a reduction in the release of norepinephrine from the Locus Coeruleus and an increase in the activity of inhibitory interneurons (GABA), with consequent sedation, anxiolytic action and hypnosis. This dosedependent effect occurs 20 to 30 minutes after administration ${ }^{5,7}$. Systemic administration of high doses of morphine can also alter the level of consciousness, an effect attributed to its action on $\mathrm{K}$ (kappa) receptors in the CNS. ${ }^{2}$ Similarly to other studies ${ }^{8,22,26,28}$ that have described an important sedative effect of clonidine, we observed that more than $75 \%$ of patients in both groups, were drowsy and asleep, 30 minutes after performance of the block.

Pruritus, attributed to morphine, was the most common side effect found in this research study. It occurred in $72 \%$ and $84 \%$ in groups I and II, respectively, results similar to those described in the literature where $85 \%$ of pruritus is reported 45 minutes after the use of $100 \mu \mathrm{g}$ subarachnoid morphine for cesarean section ${ }^{7,19}$.

\section{Conclusion}

Morphine and clonidine to low doses of hyperbaric bupivacaine produced adequate anesthesia for cesarean section and good postoperative analgesia, without any maternal and fetal repercussions.

\section{References}

1. Dyer RA, Joubert IA. Low-dose spinal anaesthesia for Caesarean section. Curr Opin Anaesthesiol. 2004;17(4):301-8.

2. Karaman S, Kocabas S, Uyar M, Hayzaran S, Firat V. The effects of sufentanil or morphine added to hyperbaric bupivacaine in spinal anaesthesia for caesarean section. Eur $\mathrm{J}$ Anaesthesiol. 2006;23(4):285-91.

3. Braga Ade F, Braga FS, Potério GM, Pereira RI, Reis E, Cremonesi E. Sufentanil added to hyperbaric bupivacaine for subarachnoid block in Caesarean section. Eur J Anaesthesiol. 2003;20(8):631-5.

4. Elia N, Culebras X, Mazza C, Schiffer E, Tramèr MR. Clonidine as an adjuvant to intrathecal local anesthetics for surgery: systematic review of randomized trials. Reg Anesth Pain Med. 2008;33(2):15967.

5. Alves TCA, Braz JRC, Vianna PTG. $\alpha 2$-agonistas em anestesiologia: Aspectos clínicos e farmacológicos. Rev Bras Anestesiol. 2000;50(5):396-404.

6. Sng BL, Lim Y, Sai ATH. An observational prospective cohort study of incidence and characteristics of failed spinal anaesthesia for caesarean section. Int J Obstet Anesth. 2009;18(3):237-41

7. Neves JF, Monteiro GA, Almeida JR, Sant'anna RS, Saldanha RM, Moraes JM, Nogueira ES, Coutinho FL, Neves MM, Araújo FP, Nóbrega PB. Analgesia pós-operatória para cesariana. A adição de clonidina à morfina subaracnóidea melhora a qualidade da analgesia? Rev Bras Anestesiol. 2006;56(4):370-6.

8. Lavand'homme PM, Roelants F, Waterloos H, Collet V, De Kock MF. An evaluation of the postoperative antihyperalgesic and analgesic effects of intrathecal clonidine administered during elective cesarean delivery. Anesth Analg. 2008;107(3):948-55.

9. Braga AA, Frias JAF, Braga F, Torres NA. Raquianestesia em cesárea. Estudo comparativo da associação da bupivacaína hiperbárica com morfina e clonidina. RAMB. 2009;(Supp):67-8.

10. Filos KS, Goudas LC, Patroni O, Polyzou V. Intrathecal clonidine as a sole analgesic for pain relief after cesarean section. Anesthesiology. 1992;77(2):267-74.

11. Braz JR, Koguti ES, Braz LG, Croitor LB, Navarro LH Effects of clonidine associated to hyperbaric bupivacaine during high-level spinal anesthesia. Rev Bras Anestesiol. 2003;53(5):561-72.

12. Bogra J, Arora N, Srivastava P - Synergistic effect of intrathecal fentanyl and bupivacaine in spinal anesthesia for Cesarean section. BMC Anesthesiology. 2005;17;5(1):5-10.

13. Pedersen H, Santos AC, Steinberg ES, Schapiro HM, Harmon TW, Finster M. Incidence of visceral pain during cesarean section: the effect of varying doses of spinal bupivacaine. Anesth Analg. 1989;69(1):46-9.

14. Choi DH, Ahn HJ, Kim MH. Bupivacaine-sparing effect of fentanyl in spinal anesthesia for cesarean delivery. Reg Anesth Pain Med. 2000;25(3):240-5.

15. Braga Ade F, Frias JA, Braga FS, Pinto DR. Spinal block with $10 \mathrm{mg}$ of hyperbaric bupivacaine associated with 5 microg of sufentanil for cesarean section. Study of different volumes. Rev Bras Anestesiol. 2010;60(2):69-73.

16. das Neves JF, Monteiro GA, de Almeida JR Sant'Anna RS, Bonin HB, Macedo CF. Phenylephrine for blood pressure control in elective cesarean section: therapeutic versus prophylactic doses. Rev Bras Anestesiol. 2010;60(4):391-8.

17. Simon L, Boulay G, Ziane AF, Noblesse E, Mathiot JL, Toubas MF, Hamaza J. Effect of injection rate on hypotension associated with spinal anesthesia for cesarean section. Int J Obstet Anaesth. 2000;9(1):10-4.

18. Bliacheriene F, Carmona MJ, Barretti Cde F, Haddad CM, Mouchalwat ES, Bortolotto MR, Francisco RP, Zugaib M. Use of a minimally invasive uncalibrated cardiac output monitor in patients undergoing cesarean section under spinal anesthesia: report of four cases. Rev Bras Anestesiol. 2011;61(5):610-8.

19. Sibilla C, Albertazz P, Zatelli R, Martinello R. Perioperative analgesia for caesarean section: comparison of intrathecal morphineand fentanyl alone or in combination. Int J Obstet Anesth. 1997;6(1):43-8.

20. Dahl JB, Jeppesen IS, Jørgensen H, Wetterslev J, Møiniche S. Intraoperative and postoperative analgesic efficacy and adverse effects of intrathecal opioids in patients undergoing cesarean section with spinal anesthesia: A qualitative and quantitative systematic review of randomized controlled trials. Anesthesiology. 1999;91(6):1919-27.

21. Palmer CM, Emerson S, Volgoropolous D, Alves D. Dose-response relationship of intrathecal morphine for postcesarean analgesia. Anesthesiology. 1999;90(2):437-44.

22. Paech MJ, Pavy TJ, Orlikowski CE, Yeo ST, Banks SL, Evans $\mathrm{SF}$, Henderson J. Postcesarean analgesia with spinal morphine, clonidine, or their combination. Anesth Analg. 2004;98(5):1460-6.

23. Sarvela J, Halonen P, Soikkeli A, Korttila K. A double-blinded, randomized comparasion of intrathecal and epidural morphine for elective cesarean delivery. Anesth Analg. 2002;95(2):436-40.

24. de Souza VP, do Amaral JL, Tardelli MÂ, Yamashita AM. Effects of prophylactic continuous infusion of phenylephrine on reducing the mass of local anesthetic in patients undergoing spinal anesthesia for cesarean section. Rev Bras Anestesiol. 2011;61(4):409-24.

25. Rathmell JP, Lair TR, Nauman B. The role of intrathecal drugs in the treatment of acute pain. Anesth Analg. 2005;101(5 Suppl):S30-43.

26. Kothari N, Bogra J, Chaudhary A K. Evaluation of analgesic effects 
of intrathecal clonidine along with bupivacaine in cesarean section. Saudi J Anaesth. 2011;5(1):31-5.

27. van Tuijl I, van Klei WA, van der Werff DB, Kalkman CJ. The effect of addition of intrathecal clonidine to hyperbaric bupivacaine on postoperative pain and morphine requirements after caesarean section: a randomized controlled trial. Br J Anaesth. 2006;97(3):36570.

28. Benhamou D, Thorin D, Brichant JF, Dailland P, Milon D, Schneider M. Intrathecal clonidine and fentanyl with hyperbaric bupivacaine improves analgesia during cesarean section. Anesth Analg. 1998;87(3):609-13.

29. Strebel S, Gurzeler JA, Schneider MC, Aeschbach A, Kindler $\mathrm{CH}$. Small-dose intrathecal clonidine and isobaric bupivacaine for orthopedic surgery: a dose-response study. Anesth Analg. 2004;99(4):1231-8,

30. Fonseca NM, Oliveira CA. Efeito da clonidina associada à bupivacaína a $0,5 \%$ hiperbárica na anestesia subaracnóidea. Rev Bras Anestesiol. 2001;51(6):483-92

\section{Correspondence:}

Angélica de Fátima de Assunção Braga

Avenida Dr. José Bonifácio Coutinho Nogueira, 225/61 Torre D

13091-611 Campinas - SP Brasil

Tel.: (55 19)3521-9560

franklinbraga@terra.com.br

Received: September 3, 2012

Review: October 10, 2012

Accepted: November 28, 2012

Conflict of interest: none

Financial source: none

${ }^{1}$ Research performed at Department of Anesthesiology, Faculty of Medical Sciences, Campinas University (UNICAMP), Sao Paulo, Brazil. 